\title{
PENINGKATAN KEMAMPUAN SOFT-SKILL MAHASISWA: STUDI IMPLEMENTASI KEBIJAKAN PENERBITAN SURAT KETERANGAN PENDAMPING IJAZAH BAGI LULUSAN UNP PADANG
}

\author{
Cleh: Emizal Amri \& Reno Fernandes
}

\begin{abstract}
ABSTRAK
Artikel ini dikembangkan dari penelitian tentang Implementasi Kebijakan Penerbitan Surat Keterangan Pendamping Ijazah bagi lulusan UNP. Dalam rangka menindaklanjuti SKPI sebagaimana tertuang dalam Permendikbud No. 81 Tahun 2014, pada tgl 28 Januari 2015 UNP mengeluarkan Surat Edaran No. 0141/UN35.11/AK/2015 tentang Upload Dokumen Bukti Prestasi sebagai Bahan Pembuatan Surat Keterangan Pendamping Ijazah (SKPI) oleh Calon Wisudawan/ wati Universitas Negeri Padang Periode ke-102 (Maret 2015). Dokumen yang bisa diuploadkan itu adalah kegiatan dan prestasi dalam bidang ekstrakurikuler dan/atau soft skill yang memenuhi persyaratan tertentu. Meskipun secara formal UNP sudah menerapkan kebijakan itu sejak wisuda periode ke-102, namun hingga wisuda periode ke-104 wisudawan/ wati yang meng-uploadkan dokumen untuk pengisian SKPI baru sekitar 14\%, sementara lebih dari 85\% tidak mengisinya. Hasil penelitian menunjukkan, rendahnya upload dokumen untuk pengisian SKPI oleh wisudawan/ wati disebabkan: (1) UNP terlalu responsif untuk memberlakukan SKPI tanpa melakukan sosialisasi secara intensif; (2) mayoritas wisudawan (2015) dan juga calon wisudawan/wati berikutnya (Maret 2016) belum memahami SKPI dengan baik, dan mereka juga tidak proaktif untuk mencari tahu tentang hal itu; (3) sosialisasi SKPI oleh pihak kompeten di UNP kepada kelompok sasaran hingga kini masih amat terbatas, terutama hanya melalui web, blog, pidato resmi pejabat terkait pada acara wisuda, PKKMB, seminar, dan sejenisnya; dan (4) untuk mengantisipasi rendahnya wisudawan yang menguploadkan dokemen untuk pengisian SKPI, sepanjang tahun 2015 UNP sudah melakukan beberapa langkah strategis, seperti: mnyusun Pedoman Kegiatan Kemahasiswaan Melalui Kredit Prestasi Ekstrakurikuler yang memuat sekitar 67 kegiatan yang berpeluang untuk pengisian SKPI; mendorong dan memberikan reinforcement bagi mahasiswa yang berhasil meraih prestasi dalam berbagai even nasional, dan lain-lain sejenisnya.
\end{abstract}

Keyword: SKPI, Soft Skill, Wisudawan

\section{Pendahuluan}

Perkembangan dan persaiangan global menyebabkan negara-negara maju dan Dunia Ketiga berusaha mengembangkan kompetensi sumber daya manusia dalam semua aspek kehidupan masyarakat. Salah satu implikasinya adalah tuntutan kepada perguruan tinggi/ universitas untuk selalu meningkatkan mutu luarannya. Untuk kepentingan tersebut, pemerintah telah mengeluarkan Peraturan Presiden Republik Indonesia No. 8 Tahun 2012 tentang Kerangka Kualifikasi Nasional Indonesia. 
Dalam rangka menindaklanjuti Perpres tentang Kerangka Kualifikasi Nasional Indonesia (KKNI) untuk perguruan tinggi, Menteri Pendidikan dan Kebudayaan telah mengeluarkan Permendikbud Nomor 81 Tahun 2014 tentang Ijazah, Sertifikat Kompetensi, dan Sertifikat Profesi Pendidikan Tinggi. Di dalam permendikbud itu secara tegas dituliskan, selain mengeluarkan Ijazah, Sertifikat Profesi, dan Sertifikat Kompetensi, perguruan tinggi juga harus menerbitkan "Surat Keterangan Pendamping Ijazah" (SKPI, Diploma Supplement) bagi lulusannya. SKPI itu berisi informasi tentang berbagai kegiatan mahasiswa di luar kelas formal (perkuliahan).

SKPI itu dinilai strategis, mengingat sejak beberapa tahun terakhir ini dalam proses rekruitmen pegawai, banyak institusi/perusahaan tidak hanya mengandalkan ijazah dan Indeks Prestasi Kumulatif semata, tetapi juga menuntut kemampuan soft skill (kemampuan sosial, kepemimpinan, pengalaman kerja, dan riwayat organisasi). Berbagai potensi terakhir itulah yang dapat dipantau melalui SKPI yang dikeluarkan oleh perguruan tinggi terkait. Mengingat begitu urgennya SKPI itu, lalu pada tgl 28 Januari 2015 UNP mengeluarkan Surat Edaran No. 0141/UN35.11/AK/2015 tentang Upload Dokumen Bukti Prestasi sebagai Bahan Pembuatan Surat Keterangan Pendamping Ijazah (SKPI) oleh Calon Wisudawan/wati Universitas Negeri Padang Periode ke-102 (Maret 2015). Kemudian untuk kepentingan tersebut UNP telah membangun suatu sistem dokumentasi rekam jejak prestasi mahasiswa yang dapat diupload ke dalam aplikasi SIPRESMA (http://sipresma.unp.ac.id/). Pada gilirannya dokumen yang dinyatakan memenuhi kriteria oleh validator dapat dimanfaatkan untuk pengisian Diploma Suplement (SKPI).

Data yang didapat dari UPT Pusat Komputer UNP pada wisuda ke-102 Maret 2015, ternyata hanya 283 dari 2.800 wisudawan yang meng-inputkan dokumen kegiatan dan prestasi soft-skill yangdiperoleh selama kuliah ke dalam aplikasi SIPRESMA UNP. Selanjutnya pada wisuda periode ke-103 (Juni 2015) hanya 106 orang dari 1.014 wisudawan/ ti yang menginputkan data untuk pengisian SKPI. Bahkan pada wisuda periode ke-104 juga belum terdapat peningkatan yang signifikan dari wisudawan yang meng-upload-kan data untuk pengisian SKPI. Selama tiga kali wisuda, sejak pemberlakuan Surat Edaran No. 0141/UN35.11/AK/2015, baru sekitar $14 \%$ wisudawan yang meng-uploadkan dokumen untuk pengisian SKPI, sementara lebih dari $86 \%$ SKPI-nya hanya berisi keterangan sesuai dengan spesifikasi dan kualifikasi lulusan dari prodi yang diikuti selama ini.

Bertolak dari pokok persoalan di atas, menarik untuk mendeskripsikan dan menganalisis implementasi kebijakan SKPI dalam kaitannya dengan pengembangan kemampuan soft skill mahasiswa di UNP. Sehubungan dengan itu, berikut diajukan beberapa pertanyaan lebih spesifik: (1) bagaimana respon UNP terhadap kebijakan penerbitan SKPI ?; (2) mengapa masih sedikt wisudawan UNP yang meng-uploadkan dokumen untuk pengisian SKPI; dan (3) bagaimana upaya yang telah dilakukan pihak kompeten di UNP guna pengembangan kemampuan soft skill mahasiswa ?. 
Jawaban terhadap pertanyaan pokok di atas, diduga dapat membangun pemahaman dan persepsi positif terhadap SKPI, sehingga pengembangan soft-skill ke depan tidak lagi terabaikan. Dengan begitu, secara praktis jumlah mahasiswa yang meng-inputkan dokumen untuk pengisian SKPI akan meningkat dengan sendirinya.

Bertolak dari kenyataan seperti dimukakan di atas, kajian ini dinilai sangat urgen mengingat: pentingnya pengembangan kemampuan soft skill lulusan perguruan tinggi yang dituangkan dalam diploma SKPI guna memberbesar margin untuk dapat diterima dalam pasar dunia kerja. Persoalan ini kian menarik untuk dikaji secara mendalam mengingat, di saat tuntutan dunia kerja mulai mengharuskan sertifikat yang menggambarkan kemampuan soft skill seseorang.

\section{Surat Keterangan Pendamping Ijazah}

Dalam era global dan menguatnya tuntutan akan profesionalisme, serta kemampuan hard skill dan soft skill lulusan institusi pendidikan, pemerintah perlu menetapkan standar kelulusan dari lembaga pendidikan di Indonesia. Sehubungan dengan itu, Pemerintah Republik Indonesia mengeluarkan Peraturan Presiden Republik Indonesia Nomor 8 Tahun 2012 tentang Kerangka Kualifikasi Nasional Indonesia. Peraturan ini telah memberikan dorongan sekaligus dukungan bagi pengembangan sebuah ukuran kualifikasi lulusan pendidikan di Indonesia dalam bentuk sebuah kerangka kualifikasi, yang kemudian lebih dikenal dengan KKNI.

Dilihat dari satu sisi, KKNI menjadi sebuah tonggak sejarah baru (milestone) bagi dunia pendidikan tinggi di Indonesia dalam upaya menghasilkan lulusan yang berkualitas dan berdaya saing tinggi, bukan hanya di tingkat nasional dan regional, tetapi juga pada tataran global. Di sisi lain, KKNI juga dapat digunakan sebagai tolok ukur dalam penyusunan capaian pembelajaran pada program studi tertentu di perguruan tinggi. Dapat dikatakan demikian karena di dalam KKNI: selain dituntut pengembangan kemapuan hard skill, perguruan tinggi juga diharuskan untuk mendorong dan mempersiapkan soft skill bagi lulusannya.

Untuk pengakuan prestasi mahasiswa dalam bidang keilmuan dan profesi, selama ini perguruan tinggi (termasuk UNP) lazimnya mengeluarkan dokumen resmi berupa Ijazah, dan Transip Nilai sebagai bukti telah menamatkan kuliah pada prodi tertentu. Kedua dokumen/ sertifikat tersebut, ternyata hanya memberikan gambaran tentang prestasi akademik hard skill seorang mahasiswa, sedangkan soft skill dan potensi lainnya tidak bisa dideteksi melalui hal itu. Sementara potensi soft skill yang disebut O'brien (1997) dengan winning characteristics (keahlian berkomunikasi; keahlian berorganisasi; kepemimpinan; kemampuan berfikir logis; semangat juang (effort), serta kemampuan berkelompok, dan etika) sang mahasiswa selama di perguruan tinggi sejauh ini tidak mendapatkan legitimasi (pengakuan) dari lembaga. Hal terakhir inilah yang akan mendapatkan pengakuan resmi dari lembaga melalui Surat Keterangan Pendamping Ijazah. 
Di dalam Permendikbud Nomor 81 Tahun 2014 didefinisikan, bahwa "Surat Keterangan Pendamping Ijazah (SKPI) atau Diploma Supplement adalah surat pernyataan resmi yang dikeluarkan oleh Perguruan Tinggi, berisi informasi tentang pencapaian akademik atau kualifikasi dari lulusan pendidikan tinggi bergelar". Menurut Liliana Sugiharto, kualifikasi lulusan diuraikan dalam bentuk narasi deskriptif yang menyatakan capaian pembelajaran lulusan pada jenjang KKNI yang relevan, dalam suatu format standar yang mudah dipahami oleh masyarakat umum. Namun SKPI bukan pengganti dari ijazah, dan juga bukan transkrip akademik. Bahkan juga dinyatakan SKPI bukan pula media yang secara otomtis memastikan pemegangnya mendapatkan pengakuan pihak lain, termasuk dunia kerja. Definisi dalam Permendikbud: "SKPI...........berisi informasi tentang pencapaian akademik ....." ini justru mengundang kerancuan dan mengundang serangkaian problem dalam pengimplementasiannya di lapangan, sermasuk pengalaman penerapan SKPI di UNP.

Bagaimanapun, dalam perkembangannya kemudian SKPI merupakan dokumen tambahan yang mengindikasikan kemampuan teknis yang dibutuhkan dunia kerja, penguasaan pengetahuan di luar bidang keilmuan, dan sikap/ moral seorang lulusan. SKPI itu dimaksudkan untuk memetakan pengalaman dan prestasi soft skill seseorang, sehingga ia bisa memetakan kelayakan kerja (employability) bagi setiap pemegangnya Di sinilah sebernarnya urgensi SKPI sebagai pendamping ijazah yang hanya menyiratkan potensi akademik ( hard skill) pemiliknya.

Di dalam pasal 5 ayat 1 Permendikbud No. 81 Tahun 2014 ditegaskan: Ijazah diberikan kepada lulusan perguruan tinggi setidaknya disertai Transkrip Akademik dan Surat Keterangan Pendamping Ijazah. Ijazah dan Transkrip Akademik adalah dua hal yang sudah lazim diberikan kepada setiap lulusan perguruan tinggi. Namun SKPI merupakan inovasi baru yang diintrodusi pemerintah ke perguruan tinggi, di mana perguruan tinggi diharuskan mengeluarkan sertifikat sebagai pengakuan terhadap potensi soft skill lulusannya.

Pada pasal 7 ayat (1) Permendikbud No 81/2014 di atas antara lain berisi identitas lembaga dan pemegang SKPI secara rinci. Sementara pasal 7 ayat (2) berbunyi: "SKPI sebagaimana dimaksud pada ayat (1) dapat memuat: (a) informasi tambahan tentang prestasi lulusan selama berstatus mahasiswa; dan/ atau (b) jabatan dalam profesi." SKPI itu baru boleh diterbitkan bila seorang mahasiswa sudah dinyatakan lulus secara resmi oleh perguruan tinggi terkait, dan bukan diperuntukkan bagi mahasiswa yang sedang aktif kuliah. Terakhir, penerima SKPI harus dicantumkan dalam situs resmi perguruan tinggi tempat yang bersangkutan berasal.

\section{SKPI dan Respon Perguruan Tinggi}

Hingga kini respon perguruan tinggi terhadap SKPI sebagai inovasi yang digulirkan Kemendikbut melalui Permendikbud No. 81/2014 masih mengundang pro dan kontra. Namun UNP dan sejumlah universitas lainnya, memandang SKPI itu 
sebgai suatu yang penting dan strategis dalam percaturan global di masa datang, lalu meresponnya dengan segera. Hanya dalam rentang waktu kurang dari empat bulan setelah Permendikbud itu diundangkan, UNP menyatakan siap menindaklanjutinya. Buktinya pada tanggal 28 Januari 205 UNP mengeluarkan Surat Edaran Nomor 0141/UN35.11/AK/2015 tentang Upload Dokumen Bukti Prestasi sebagai Bahan Pembuatan Surat Keterangan Pendamping Ijazah (SKPI) oleh Calon Wisudawan/wati Universitas Negeri Padang Periode ke-102 (Maret 2015).

Di dalam edaran itu antara lain ditegaskan, agar calon wisudawan/wati UNP Periode ke-102 meng-upload sendiri scan dokumen bukti prestasi (sertifikat, piagam, surat keterangan, surat keputusan, sertifikat HKI, kartu anggota, dan dokumen relevan lainnya) yang diraih selama menjadi mahasiswa. Scan dokumen itu di-upload ke dalam aplikasi SIPRESMA (http://sipresma.unp.ac.id/), selanjutnya akan divalidasi oleh petugas yang ditunjuk secara resmi oleh universitas. Dalam poin 1 Surat Edaran itu ditegaskan, dokumen prestasi yang bisa di-upload meliputi enam bidang, yaitu: (a) pemenang Lomba atau Kejuaraan, seperti Perlombaan Olahraga, MTQ, dll; (b) organisasi kemahasiswaan, seperti HIMA, BEM, dll; (c) Bahasa Internasional, seperti: TOEFL, IELTS, TOEIC, dll; (d) penelitain/ Pengabdian Masyarakat, yaitu ikut terlibat/ menjadi anggota dalam penelitain/ pengabdian masyarakat yang dilakukan oleh dosen UNP; (e) prestasi non-perlombaan, meliputi: Pertukaran Pelajar/ Pemuda Internasional, penulisan literatur/ karya tulis yang sudah dipublikasikan, Narasumber/ pemateri dalam seminar, dan sejenisnya; dan (f) Inovasi/ penemuan, penemuan alat baru, dll yang terdaftar di Ditjen HKI. Poin (1) itu ditutup dengan penegasan: "prestasi selain yang disebutkan di atas tidak diterima dan tidak dicetak dalam SKPI."

Selain melalui surat edaran di atas, sosialisasi mengenai kebijakan mulai diberlakukannya Penerbitan SKPI bagi lulusan UNP, juga dilakukan melalui portal akademik UNP, serta blangko pendaftaran wisuda periode ke-102 (Maret 2015). Dalam kaitan itu, di tingkat fakultas, Kasubag/ staf Kemahasiswaan dan juga Akademik, admin tiap-tiap prodi telah berperan aktif dalam membantu pengisian form SKPI bagi tiap-tiap lulusan yang memiliki data soft-skill relevan. Sehubungan dengan kebijakan baru ini, secara khusus Rektor UNP telah menjelaskan tentang pentingnya SKPI dalam pidato resminya pada acara wisuda ke-102 itu. Hal yang sama umumnya juga disampaikan oleh Dekan di masing-masing fakultas dalam pidato pengantar pembagian Ijazah dan Transip Akademik. Pasca wisuda periode Maret 2015, sosialisasi SKPI juga telah dilakukan dengan memanfaatkan berbagai media, seperti: koran kampus Ganto dalam beberapa terbitannya sudah mengulas SKPI; memuat berita/ informasi tentang SKPI dalam web dan blog fakultas, jurusan/ prodi di lingkungan UNP, baik diprakarsai oleh tim IT fakultas ataupun admin di tingkat jurusan/ prodi; serta pidato dari pejabat kompeten dalam momen tertentu, seperti dalam kegiatan PKKMB, seminar, workshop, dan sebagainya. 
Meskipun SKPI sudah disosialisasikan oleh pihak kompeten di UNP melalui berbagai media, tetapi belum ada forum resmi yang langsung menyentuh kelompok sasaran. Akibatnya esensi dan manfaat SKPI tidak dipahami secara baik dan benar oleh wisudawan atau mahasiswa tingkat akhir sebagai kelompok sasaran. Buktinya, mayoritas wisudawan periode ke-102 menyatakan tidak mengetahui tentang SKPI. Kebanyakan di antara mereka kaget, ketika mendapatkan pengumuman dalam bundelan pendaftaran wisuda agar meng-upload-kan dokumen relevan guna pengisian SKPI. Alhasil pada wisuda UNP periode ke-102 (Maret 2015) hanya 283 dari 2.800 wisudawan/ wati yang meng-upload-kan dokumen untuk pengisian SKPI, sementara pada wisuda periode ke-103 (Juni 2015) hanya 106 dari 1.041 wisudawan. Kemudian pada wisuda periode ke-104 (September 2015), prosentasenya relatif sama (dalam artian tidak terjadi peningkatan berarti). Pada hal pasca wisuda periode ke-102, sosialisasi SKPI sudah dilakukan melalui koran kampus, media cetak dan elektronik/ TI. Walaupun demikian mayoritas mahasiswa UNP tingkat akhir (calon wisuda) tetap menyatakan tidak tidak tahu tentang SKPI. Sisanya sudah mendengar SKPI, tetapi belum mengetahui esensi dan manfaatnya dengan baik dan benar.

Jika SKPI dipahami sebagai inovasi yang diintrodusir Kemendikbud ke perguruan tinggi, maka realitas di atas menarik untuk dikritisi dengan memanfaatkan teori difusi inovasi. Menurut, Rogers (1983) penerimaan terhadap inovasi, terutama ditentukan oleh keberhasilan agen pembaharu dalam menyosialisasikan dan menjelaskan mafaat yang bisa didapat kelompok sasaran bila mengadopsinya. Di sinilah titik lemah dari implementasi kebijakan penerbitan SKPI bagi lulusan UNP. Meskipun UNP sebagai agen sudah melakukan sosialisasi, tetapi belum menyentuh kelompok sasaran secara langsung. Akibatnya, kelompok sasaran tidak memahami esensi dan manfaat SKPI dengan benar. Selain itu, penerapan kebijakan penerbitan SKPI secara mendadak, telah mengakibatkan wisudawan yang sudah memahami manfaatnya, tidak bisa berbuat banyak karena mereka tidak memiliki dokumen yang memenuhi persyaratan untuk di-upload-kan.

Sejak wisuda Periode ke-102 (Maret 2015) hingga wisuda periode ke-104 (September 2015) baru sekitar 14\% dari alumni UNP yang sudah meng-upload-kan dokumen untuk pengisian SKPI. Itupun kebanyakan hanya terbatas pada: pengalaman menjadi pengurus organisasi kemahasiswaan; sertifikat TOEFL; serta pemenang lomba/ kejuaraan tertentu. Sementara pengalaman lainnya, seperti keterlibatan mahasiswa dalam kegiatan penelitian dan pengabdiaan pada masyarakat bersama dosen tertentu, hingga kini belum ada dokumen untuk pembuktiannya. Akibatnya tidak ada dokumen yang bisa di-scan dan diinputkan oleh wisudawan ke dalam aplikasi SIPRESMA guna pengisian SKPI.

Pada wisuda periode ke-104 (September 2015) masih lebih dari 80\% lulusan UNP yang belum mengisi SKPI sesuai dengan pengalaman dan prestasi soft skill yang didapat selama kuliah di almamater mereka. Hal itu diduga erat kaitannya dengan 
arah kebijakan UNP sebelumnya: selama ini (baik unsur pimpinan, dosen maupun mahasiswa) tidak/ belum menempatkan pengembangan potensi soft skill dalam skala prioritas. Konsekuensinya, ketika lulusan diminta untuk meng-upload dokumen pengalaman dan prestasi soft skill untuk pengisian SKPI, relatif terbatas mahasiswa yang memilikinya. Akibatnya, sampai wisuda periode ke-104 (September 2015) lebih dari $80 \%$ lulusan UNP, SKPI-nya hanya berisi keterangan kewenangan lulusan sesuai dengan learning out-come prodi mereka masing-masing.

Walaupun demikian, problema implementasi SKPI seperti dikemukakan di atas, tidak bisa dibebankan sepenuhnya pada lembaga. Bagaimanapun inisiatif dari kelompok sasaran adalah sesuatu yang tidak kalah pentingnya. Dikatakan demikian, karena menurut Lerner (1983) "melek huruf merupakan wahana untuk membuka cakrawala seseorang/ sekelompok orang. Dengan melek huruf akan terbuka bagi seseorang untuk mengakses informasi dari luar melalui membaca, sehingga dia akan adaptif terhadap ide-ide atau produk baru." Realitas yang terjadi di kalangan kebanyakan mahasiswa UNP, kelihatannya tidak bisa dijelaskan dengan konsepsi Lerner. Sebagai elit terpelajar, mahasiswa tidak hanya sekedar melek huruf, tetapi mereka umumnya sudah melek teknologi informasi. Mahasiswa sudah sangat familiar dengan IT, dan umumnya setiap hari mereka membuka internet. Hanya saja, kebanyakan mereka belum menggunakan IT untuk mencari informasi/ temuan baru, melainkan hanyalah sebagai hiburan, terutama dengan membuka Face Book (fb). Buktinya, SKPI yang sudah banyak diinformasikan di internet/ media sosial tidak menjadi perhatian bagi kebanyakan mahasiswa (calon wisudawan) lembaga ini.

\section{Kebijakan Penerbitan SKPI dan Pengembangan Soft Skill Mahasiswa}

Dihadapkan pada problema seperti dikemukakan di atas, sejak setahun terakhir ini UNP telah mengambil beberapa langkah/kebijakan strategis. Salah satu di antaranya menyusun buku "Pedoman Kegiatan Kemahasiswaan Melalui Kredit Prestasi Ekstrakurikuler" bagi mahasiswa UNP. Pedoman pengelolaan kegiatan kemahasiswaan ini mempunyai karakteristik khusus, yaitu: "setiap mahasiswa harus mengikuti kegiatan kemahasiswaan; dan setiap kegiatan mempunyai nilai kredit." Dalam kaitan ini, setiap mahasiswa UNP diwajibkan untuk mengembangkan diri dan memupuk soft skill melalui beraneka ragam kegiatan ekstrakurikuler. Tujuannya tidak lain adalah untuk melahirkan tamatan yang berkualitas dan berdaya saing. Secara tidak langsung nilai kredit yang dikumpulkan mahasiswa melalui kegiatan tersebut, pada gilirannya bisa dimafaatkan untuk pengisisian SKPI.

Program pengembangan potensi dan kemampuan soft skill tersebut disusun dengan mengacu pada kondisi mahasiswa saat ini, serta tuntutan/ kebutuhan dunia kerja. Kegiatan dalam program pengembangan kemahasiswaan itu dalam panduan di atas pada hakikatnya dapat dikategorikan ke dalam empat kelompok, yaitu: penalaran dan keilmuan; bakat, minat dan kemampuan; kesejahteraan; dan kegiatan 
penunjanglainnya. Berikut akan dijelaskan bentuk kegiatan dalam masing-masing kategori tersebut secara simultan.

Pertama, penalaran dan keilmuan. Program ini bertujuan untuk menanamkan sikap ilmiah, merangsang daya kreasi dan inovasi, peningkatan kemampuan penelitian dan penulisan karya ilmiah, pemahaman profesi, peningkatan kemampuan bahasa Inggris dan kerjasama mahasiswa dalam tim, baik inter maupun antar perguruan tinggi. Kedua, bakat, minat dan kemampuan. Program ini bertujuan untuk meningkatkan kemampuan mahasiswa dalam managemen praktis, berorganisasi, menumbuhkan apresiasi terhadap olah raga dan seni, kepramukaan, bela negara, cinta alam, jurnalistik, dan bakti sosial. Ketiga, kesejahteraan. Program ini dimaksudkan untuk meningkatkan kesejahteraan fisik, mental, dan kerohanian mahasiswa. Keempat, kegiatan penunjang yang bertujuan untuk meningkatkan sikap dan kemampuan dosen dalam keterlibatannya membimbing kegiatan kemahasiswaan. Wujud kegiatannya adalah berupa: (1) pelatihan orientasi pengembangan pendamping kemahasiswaan; (2) pelatihan keterampilan managemen mahasiswa; dan (3) pelatiahan pembimbing/pendamping penalaran mahasiswa (PPPM).

Selanjutnya di dalam panduan tersebut, dirinci jenis kegiatan yang termasuk ke dalam setiap kelompok/ bidang kegiatan, lengkap dengan nilai kreditnya masingmasing. Kelompok/ bidang kegiatan tersebut mencakup: (1) penalaran dan keilmuan terdiri dari 12 jenis kegiatan; (2) bakat, minat, dan kemampuan meliputi 14 macam kegiatan; (3) bidang kesejahteraan terdiri dari 7 jenis kegiatan; (4) pengabdian pada masyarakat mencakup 6 jenis kegiatan; dan tambahan (5) penerima penghargaan dengan enam jenis/tingkatannya. Rincian jenis dan angka kredit untuk setiap kegiatan itu sudah tertuang dengan jelas dalam Pedoman Kegiatan Kemahasiswaan Melalui Kredit Prestasi Ekstrakurikuler (pp. 12-19). Walaupun demikian, ada berbagai macam kegiatan mahasiswa yang bereputasi nasional yang belum terakomodasi dalam aplikasi SIPRESMA, misalnya: kegiatan Pekan Kreativitas Mahasiswa. Pada hal proposal kegiatan yang dinyatakan lulus untuk dibiayai sudah mendapatkan Lembaran Pengesahan dari Dikti, tetapi ia tidak bisa dijadikan bukti dalam rangka pengisian SKPI. Fenomena demikian masih terjadi hingga wisuda periode ke-104, di mana masih banyak kegiatan dan prestasi soft skill mahasiswa yang belum bisa diisikan ke dalam sertififat SKPI.

Pedoman Kegiatan Kemahasiswaan Melalui Kredit Prestasi Ekstrakurikuler di atas sudah dibahas dan disahkan dalam Rapat Senat Universitas Negeri Padang pada bulan September 2015. Mengingat pedoman itu sudah mendapat legitimasi dari senat universitas, maka secara formal ia sudah bisa dijadikan acuan bagi penilaian kegiatan ekstrakurikuler dan soft skill mahasiswa dalam rangka pengisian SKPI bagi lulusan UNP wisuda periode ke-105 mendatang, dan seterusnya. Hanya saja, hingga kini buku panduan itu masih belum disosialisakan dan didistribusikan kepada pihak-pihak kompeten, seperti: calon wisuda berikut; pimpinan fakultas dan prodi di lingkungan 
UNP yang berwewenang melakukan validasi data yang di-upload-kan oleh calon lulusan untuk pengisian SKPI.

Bagaimana pun, akhir-akhir ini pihak universitas dan unit-unit yang berada di bawahnya telah mengembangkan berbagai program relevan yang pada gilirannya bisa dimanfaatkan untuk pengisian SKPI. Sepanjang tahun 2015, UNP telah meningkatkan intensitas dan kualitas kegiatan ekstrakurikuler maupun pengembangan soft skill mahasiswa dibandingkan dengan tahun-tahun sebelumnya. Diantara program prioritas dalam kaitan itu antara lain adalah: (1) kursus/ pelatihan bahasa Inggris yang dibiayai dengan dana 'bidik misi,' tetapi program ini terbuka diikuti oleh mahasiswa non-bidik misi; (2) pelatihan dan workshop kewirausahaan; (3) pelatihan jurnalistik; (4) Latihan Kepemimpinan Manajemen Mahasiswa (LKMM); (5) Pekan Kreativitas Mahasiswa (PKM) yang mencakup lima bidang kegiatan, yaitu: penelitian, penerapan teknologi, kewirausahaan, pengabdian pada masyarakat, serta artikel ilmiah; (6) mendorong keikutsertaan mahasiswa yang berprestasi untuk mengikuti berbagai even nasional, seperti: debat bahasa Inggris, lomba karya tulis ilmiah, MTQ dengan segala unit kegiatannya, debat konstitusi, Pekan Olahraga Nasional (PON), Olimpiade Sain Nasional, festival seni, karya inovatif, dan lain-lain.

Untuk meningkatkan motivasi dan minat mahasiswa mengikuti even nasional, maka UNP, fakultas, dan/ atau prodi biasanya memberikan bantuan dana sesuia dengan urgensi kegiatan dan keterkaitannya dengan POK yang telah disusun. Khusus untuk mahasiswa Bidik Misi yang mengikuti penulisan ilmiah dan kejuaraan di tingkat nasional diberikan reward, berupa uang sebanyak Rp 500.000,- (lima ratus ribu rupiah) per orang/ kegiatan. Meskipun sudah ada kontribusi atau bantuan dari lembaga, tetapi masih relatif sedikit mahasiswa UNP yang memanfaatkan peluang bagi pengembangan kemampuan soft skill tersebut.

\section{Kesimpulan}

Dalam merespon tuntutan pengembangan sumber daya manusia (SDM) dan profesionalisme pada era globalisasi ini, pemerintah Indonesia telah mengundangkan Peraturan Presiden Republik Indonesia Nomor 8/2012 tentang Kerangka Kualifikasi Nasional Indonesia (KKNI). Lebih lanjut untuk mendorong dan melegitimasi soft skill lulusan perguruan tinggi, Menteri Pendidikan dan Kebudayaan RI telah mengeluarkan Permendikbud Nomor 81 tahun 2014 tentang Ijazah, Sertifikat Kompetensi, dan Sertifikat Profesi Pendidikan Tinggi. Di dalam Permendikbud itu secara khusus diatur tentang pemberian "Surat Keterangan Pendamping Ijazah", di mana setiap perguruan tinggi diharuskan menerbitkan SKPI untuk memetakan dan sekaligus mengakui secara formal soft-skill yang dimiliki lulusannya.

Mengacu pada pokok persoalan penelitian sebagaimana dikemukakan di atas, temuan penelitian ini dapat disimpulkan sebagai berikut. Pertama, menyadari betapa 
strategis dan makna penting dari SKPI ke depan, lalu secara kelembagaan UNP segera merespon Permendikbud No. 81/ 2014. Dalam tenggang waktu kurang dari empat bulan setelah Permendikbud itu diundangkan, tepatnya tgl 28 Januari 2015 UNP telah mengeluarkan Surat Edaran No. 0141/U35.11/AK/2015 tentang Upload Dokumen Bukti Prestasi sebagai Bahan Pembuatan Surat Keterangan Pendamping Ijazah (SKPI) bagi Calon Wisudawan/ wati Universitas Negeri Padang Periode ke102 (Maret 2015). Surat edaran ini membuat kebanyakan calon wisudawan periode ke-102 menjadi kaget, skeptis dan apatis. Hal ini merupakan konsekuensi logis dari: (1) Surat edaran tersebut dinilai keluarnya amat mendadak; dan (2) sosialisasi tentang landasan kehadiran, hakikat, dan nilai guna SKPI belum dilakukan menurut mestinya.

Kedua, dalam tiga periode wisuda (Maret 2015, Juni 2015, dan September 2015), wisudawan/ wati yang meng-upload-kan dokumen untuk pengisian SKPI hanya sekitar 14\%. Sementara mayoritas wisudawan/ wati SKPI-nya hanya berisi kewenangan sesuai dengan outcome prodi yang dikuti di UNP, serta aktifitas menjadi pengurus organisasi kemahasiswaan. Hal itu disebabkan oleh berbagai faktor berikut, terutama: (1) sosialisasi SKPI oleh pihak kompeten di lembaga ini kepada kelompok sasaran (calon wisuda atau mahasiswa tingkat akhir) secara langsung dan intensif belum pernah dilakukan, melainkan hanya melalui web UNP/ puskom, blog fakultas/ jurusan, serta pidato pimpinan universitas, fakultas, jurusan/prodi pada momen tertentu seperti: acara wisuda, kegiatan PKMB, seminar, dll.; (2) hingga kini mayoritas calon wisudawan/ wati UNP belum mendengar (apalagi memahami) SKPI dengan benar; (3) minoritas mahasiswa yang sudah mendengar SKPI, umumnya tidak berusaha mencari informasi yang lebih mendalam tentang SKPI; (4) sebagian kecil mahasiswa yang sudah mengenal SKPI, tidak memiliki dokumen yang memenuhi persyaratan untuk di-upload-kan; dan (5) UNP belum membuat regulasi yang tegas untuk mendokumentasikan keterlibatan mahasiswa pada berbagai kegiatan pengembangan soft skill dan ekstrakurikuler, seperti dalam penelitian, pengabdian pada masyarat bersama dosen relevan, dan berbagai kegitan lainnya.

Ketiga, menyadari problema yang dihadapi mahasiswa dalam pengisian SKPI, akhirnya UNP dan unit-unit terkait di bawahnya telah melakukan beberapa kebijakan penting sepanjang tahun 2015. Di antara kebijakan itu yang dinilai amat strategis adalah: (1) penyusunan Pedoman Kegiatan Kemahasiswaan Melalui Kredit Prestasi Ekstrakurikuler di bawah koordinasi Wakil Rektor 3. Meskipun sudah mendapatkan legitimasi atau disahkan oleh Senat Universitas Negeri Padang, tetapi sampai saat ini pedoman itu belum disosialisasikan; (2) meningkatkan intensitas dan kualitas program pengembangan soft skill atau pun kegiatan ekstrakurikuler, terutama dengan memanfaatkan sumber dana yang tersedia (termasuk dana Bidik Misi), tetapi terbuka bagi mahasiswa non-Bidik Misi, seperti: pelatihan Bahasa Inggris; pelatihan/ workshop kewirausahaan; pelatihan jurnalistik; Latihan Kepemimpinan Manajemen Mahasiswa; Pekan Kreativitas Mahasiswa, mencakup lima bidang kegiatan (penelitian, penerapan teknologi, kewirausahaan, pengabdian pada masyarakat, serta 
artikel ilmiah); dan (3) mendorong keikutsertaan mahasiswa yang berprestasi untuk mengikuti berbagai even nasional, seperti: debat bahasa Inggris, lomba karya tulis ilmiah, MTQ dengan segala cabangnya, debat konstitusi, Pekan Olahraga Nasional, Olimpiade Sain Nasional, festival seni, karya inovatif, dan lain-lain.

Mahasiswa yang mengikuti kegiatan tersebut dan memenuhi kriteria yang ditentukan, selanjutnya diberikan surat keputusan, sertifikat dan/ ataupun piala. Kemudian hal itu bisa dijadikan dokumen kegiatan pengembangan soft skill dan/ atau ekstrakurikuler yang pada gilirannya bisa di-upload untuk pengisian SKPI segera setelah yang bersangkutan dinyatakan lulus dari prodi tertentu di UNP.

\section{Rekomendasi}

Bertolak dari temuan dan keterbatasan penelitian yang telah dilakukan, kepada peneliti yang tertarik untuk meneliti pokok persoalan serupa, direkomendasikan untuk memfokuskan penelitian pada: dampak dan/ atau pengaruh pemberlakuan kebijakan penerbitan SKPI terhadap pengembangan program soft skill mahasiswa suatu perguruan tinggi. Mengingat keterbatasan waktu, biaya, dan kesempatan, pokok persoalan ini belum sempat dikaji secara mendalam dalam penelitian yang telah dilakukan sebelumnya.

Selanjutnya dengan mencermati fenomena dan hasil penelitian ini, secara praktis dapat dirumuskan beberapa saran penting berikut Pertama, mengingat SKPI merupan program diintrodusir dari luar, maka perguruan tinggi sebagai agen pembaharu perlu menyosialisasikan program ini secara intensif dan langsung kepada kelompok sasaran (calon wisudawan dan mahasiswa tingkat akhir). Kedua, pimpinan universitas sampai ke pimpinan unit yang berada di bawahnya, serta dosen, perlu memperbaharui mindset terhadap pengembangan soft skill mahasiswa di samping pengembangan hard skill. Ketiga, mahasiswa harus proaktif untuk mencari informasi berkaitan dengan kebijakan/ regulasi yang diambil oleh Kementerian Pendidikan dan Kebudayaan (kini Kementerian Riset dan Teknologi), apalagi yang berkaitan dengan kepentingan mahasiswa sendiri. Keempat, sebagai calon akademisi, mahasiswa harus memupuk/ menumbuhkembangkan kreatifitas, dan visioner dalam merespon berbagai kebijakan yang digulirkan oleh perguruan tinggi dan kementerian terkait.

\section{DAFTAR PUSTAKA}

Depdiknas RI. 2004. Pendidikan Kecakapan Hidup: Buku I. Edisi 2. Jakarta: Depdiknas RI.

Keputusan Menteri Pendidikan Nasional Republik Indonesia no 232/U/200 tentang Pedoman Penyusunan Kurikulum Pendidikan Tinggi dan Penilaian Hasil Belajar Mahasiswa. 
Lerner, Daniel. 1983. Memudarnya Masyarakat Tradisional. Yogyakarta: Gajah Mada University Press.

Marwanti, dkk (2000). Studi Tentang Penelusuran Lulusan Jurusan Pendidikan Kesejahteraan Keluarga Fakultas Teknik UNY, Laporan Penelitian, FT UNY.

Muchlas Samawi (2004). "Upaya Merekonstruksi Ulang Pendidikan," Makalah, Konvensi Nasional Pendidikan V, Surabaya.

Nasution, Arman Hakim. Creative Thinking. Surabaya: Penerbit Andi, 2006

O'brien, Patrick S. Making College Count: A Real World Look at How to Succeed In and After College. USA: Graphic Management Corp, 1997

Pedoman Kegiatan Kemahasiswaan Melalui Kredit Prestasi Ekstrakurikuler, Padang: UNP, 2015

Peraturan Menteri Pendidikan dan Kebudayaan Republik Indonesia Nomor 73 Tahun 2013 tentang Penerapan Kerangka Kualifikasi Nasional Indonesia Bidang Pendidikan Tinggi, Jakarta: 13 Juni 2013. Kemudian Permendikbud ini dimuat dalam Berita Negara Republik Indonesia Tahun 2013 Nomor 831.

Peraturan Menteri Pendidikan dan Kebudayaan Republik Indonesia No. 81 Tahun 2014 tentang Ijazah, Sertifikat Kompetensi, dan Sertifikat Profesi Pendidikan Tinggi. Permendikbud ini kemudian dimuat dalam Berita Negara Republik Indonesia Tahun 2014 No. 1179.

Rogers, Everett M. Diffusion of Innovations (third edition). New York: Free Press, 1983

Sailah, I. Pengembangan Softskill di Perguruan Tinggi. Tim Kerja Pengembangan Softskill Direktorat Jendral Pendidikan Tinggi: Jakarta (2008)

Sugiharto, Lilian. Direktorat Pembelajaran dan Kemahasiswaan Dikti, (Bahan Presentasi 31 Oktober 2014), http:/fkep.unand.ac.id/

Universitas Negeri Padang. Surat Edaran No. 0141/UN35.11/AK/2015 tgl 28 Januari 2015 tentang Upload Dokumen Bukti Prestasi sebagai Bahan Pembuatan Surat Keterangan Pendamping Ijazah (SKPI) bagi Calon Wisudawan/wati Universitas Negeri Padang Periode ke-102 (Maret 2015). Padang, Pembantu Rektor I, 2015. Surat edaran ini juga dipublikasikan via http:/www.unp.ac.id/ 
